\title{
Pengaruh Metode Pembelajaran Dan Kecerdasan Interpersonal Terhadap Kompetensi Komunikasi Terapeutik Mahasiswa Program DIII Kebidanan Stikes Mitra Ria Husada Cibubur
}

\author{
Dina Martha ${ }^{1}$ \\ Hartati $^{2}$ \\ Zulfiati $^{3}$
}

\begin{abstract}
This study aims to determine the method of learning and interpersonal intelligence to therapeutic communication competence of DIII students Obstetrics STIKes Mitra RIA Husada. Learning methods are placed on bedside teaching methods, coaching methods and demonstrations. The method used in this research is experiment with treatment design level $3 \times 2$ with sample 48 student. The summary of this research is: 1) Bedside teaching methods can improve therapeutic communication better than coaching methods and methods of demonstration; 2) Coaching learning method can improve therapeutic communication better than demonstration; 3) The existence of interaction between learning method and intelligent interpersonal to therapeutic communication competence; 4) students who have high interpersonal intelligence, more appropriate use of bedside teaching methods; 5) students who have low interpersonal intelligence, more appropriate use of coaching learning methods than the method of demonstration.
\end{abstract}

Keywords: Learning methods, interpersonal and communication competence therapeutic

\begin{abstract}
Abstrak: Penelitian ini bertujuan untuk mengetahui pengaruh metode pembelajaran dan kecerdasan interpersonal terhadap kompetensi komunikasi terapeutik mahasiswa DIII Kebidanan STIKes Mitra RIA Husada. Metode pembelajaran dibatasi pada metode bedside teaching, metode coaching dan demonstrasi. Metode yang digunakan dalam penelitian ini adalah eksperimen dengan rancangan treatment by level $3 \times 2$ dengan sampel 48 mahasiswa. Kesimpulan penelitian ini adalah: 1) Metode pembelajaran bedside teaching dapat meningkatkan kompetensi komunikasi terapeutik lebih baik daripada metode coaching dan metode demonstrasi; 2) Metode pembelajaran coaching dapat meningkatkan kompetensi komunikasi terapeutik lebih baik daripada metode demonstrasi; 3) Terdapat interaksi antara metode pembelajaran dan kecerdasan interpersonal terhadap kompetensi komunikasi terapeutik; 4) mahasiswa yang memiliki kecerdasan interpersonal tinggi, lebih tepat menggunakan metode pembelajaran bedside teaching; 5) mahasiswa yang memiliki kecerdasan interpersonal rendah, lebih tepat menggunakan metode pembelajaran coaching daripada metode demonstrasi.
\end{abstract}

Kata kunci: Metode pembelajaran, kecerdasan interpersonal dan kompetensi komunikasi terapeutik

\section{PENDAHULUAN}

Pendidikan adalah proses yang mempunyai tujuan sasaran dan objek (Daryanto, 2008: 5). Keberhasilan pendidikan ditentu-kan oleh sejauh mana penguasaan peserta didik terhadap kompetensi Hal ini juga berlaku pada pendidikan kebidanan. Keberhasilan pendidikan kebidanan tercermin dari serangkaian kompetensi professional dikuasai oleh lulusan dihasilkannya Bidan professional yang tujuan akhir pendidikan kebidanan, terlihat dari kompetensi bidan yang harus dikuasai meliputi pengetahuan, keterampilan dan perilaku dalam melaksanakan

\footnotetext{
${ }^{1}$ Program Studi S3 Teknologi Pendidikan Pascasarjana UNJ. Email: marthadina@ymail.com 
praktek kebidanan secara aman dan bertanggung jawa pada berbagai tatanan pelayanan kesehatan (Siahaan, Sofyan dan Madjid, 2004: 146).

Salah satu kompetensi utama harus dikuasai oleh mahasiswa DIII Kebidanan adalah kompetensi komunikasi terapeutik, yaitu kompetensi dasar menjadi landasan hubungan terapeutik antara bidan dan pasien dalam kebidanan, baik hospital based maupun community based. Untuk mendukung hal tersebut pembimbing klinik ternyata belum sepenuhnya membimbing mahasiswa terutama dari segi bimbingan klinik karena pembimbing belum sepenuhnya menggunakan metode pembelajaran yang tepat yaitu metode bedside teaching dan coaching dan selama ini selalu menggunakan metode konvensional.

Selain itu, kecerdasan interpersonal dapat mempengaruhi kompetensi komunikasi terapeutik mahasiswa karena kemampuan mahaiswa dalam menjalin komunikasi secara efektif, mampu berempati secara baik, dan kemampuan mengembangkan hubungan yang harmonis dengan orang lain. Menurut Nair, Coughlan and Hensley (1997: 345), juga mengemukakan di Amerika melaporkan kesimpulan penelitiannya bahwa bedside teaching sangat efektif untuk mengajarkan keterampilan profesional karena memiliki empat fase pada proses komunikasi yaitu pra interaksi, orientasi, fase kerja serta terminasi. Menurut Piriyasupong (2015: 251), di Thailand juga melaporkan hasil penelitian bahwa metode bedside teaching efektif untuk pembelajaran evidence-based medicine yaitu konsep dasar belajar berbasis bukti ilmiah pada mahasiswa kedokteran dan didukung juga oleh Titik Puji Lestari, Susilaningsih dan Sri rahayu
(2009: 64) metode bedside teaching sangat efektif untuk meningkatkan psikomotor mahasiswa.

Tujuan utama penelitian ini adalah (1) untuk mengetahui Perbedaan kompetensi komunikasi terapeutik antara mahasiswa DIII Kebidanan STIKes Mitra RIA Husada yang dibelajarkan menggunakan metode bedside teaching dengan metode coaching dan demonstrasi, (2) untuk mengetahui interaksi antara metode pembelajaran dan kecerdasan interpersonal terhadap kompetensi komunikasi terapeutik pada mahasiswa DIII Kebidanan STIKes Mitra RIA Husada, (3) mengetahui perbedaan kompetensi komunikasi terapeutik antara mahasiswa DIII Kebidanan STIKes Mitra RIA Husada yang dibelajarkan dengan metode bedside teaching dan memiliki kecerdasan interpersonal tinggi dan rendah dengan mahasiswa yang dibelajarkan dengan metode coaching dan demonstrasi

Variabel penelitian yang diteliti adalah metode pembelajaran sebagai variabel bebas dengan kecerdasan interpersonal sebagai variabel atribut serta kompetensi komunikasi terapeutik sebagai variabel terikat. Variabel metode pembelajaran terdiri metode bedside teaching, coaching dan metode demonstrasi, serta kecerdasan interpersonal terdiri dari kecerdasan interpersonal tinggi dan rendah.

Pembimbing klinik belum sepenuhnya menggunakan metode bedside teaching yaitu pembelajaran aktif dengan kehadiran pasien sedangkan metode coaching adalah suatu proses bimbingan yang memberikan kesempatan seluasluasnya pada peserta didik baik perorangan atau kelompok untuk memecahkan permasalah sendiri didampingi fasilitator sudah digunakan. Dalam 
kondisi ini alasan yang banyak dikemukakan adalah karena metode bedside teaching dan coaching cukup menyita waktu dalam penerapannya serta belum tersedianya fakta atau bukti yang menunjukkan keberhasilan penggunaan metode bedside teaching dan coaching dalam meningkatkan penguasaan mahasiswa terhadap kompetensi komunikasi terapeutik. Selain itu, kecerdasan interpersonal dapat mempengaruhi kompetensi komunikasi terapeutik mahasiswa karena kemampuan mahasiswa dalam mejalin komunikasi secara efektif, mampu berempati secara baik, dan kemampuan mengembangkan hubungan yang harmonis dengan orang lain. Keberagaman kecerdasan interpersonal mahasiswa belum dipahami sepenuhnya oleh pengajar. Sehingga belum dapat membantu mahasiswa dalam mengembangkan kecerdasaran interpersonalnya yang secara tidak langsung juga mempengaruhi kompetensi mahasiswa.

\section{METODOLOGI PENELITIAN}

Metode yang digunakan dalam penelitian ini adalah metode eksperimen dengan rancangan treatment by level $3 \times 2$. Variabel yang diteliti adalah metode pembelajaran sebagai variabel bebas dengan kecerdasan interpersonal sebagai variabel atribut serta kompetensi komunikasi terapeutik sebagai variabel terikat. Pada penelitian ini, peneliti memberikan tes kinerja yang terdiri dari tes esai dan tes dengan daftar tilik. Tes praktek diberikan terkait tes kompetensi komunikasi terapeutik kebidanan. Populasi penelitian ini adalah mahasiswa STIKes Mitra RIA Husada yang berjumlah 76 mahasiswa, dengan jumlah sampel 48 sampel. Prosedur yang dilakukan untuk pengambilan sampel adalah sebagai berikut: 1) Mengidentifikasi seluruh mahasiswa tingkat 1 DIII Kebidanan STIKes Mitra RIA Husada yang mengikuti mata kuliah komunikasi konseling kebidanan; 2) Menetapkan mahasiswa tingkat 1 DIII Kebidanan sebagai kelas penelitian yang terdiri dari 3 kelas yaitu kelas kelompok komunikasi 1 sebagai kelas bedside teaching dengan 25 mahasiswa, kelas kelompok komunikasi 2 sebagai kelas coaching dengan 25 mahasiswa dan kelas kelompok komunikasi 3 sebagai kelas demonstrasi dengan 25 mahasiswa; 3) Ketiga kelas di tes kecerdasan interpersonal dan dikategorikan kecerdasan interpersonal tinggi dan rendah. Kecerdasan interpersonal tinggi ditetapkan berdasarkan 33\% dari urutan nilai teratas dan kecerdasan interpersonal rendah ditetapkan 33\% dari urutan nilai terbawah. Dengan demikian diketahui rentang skor masing-masing kategori; 4) Berdasarkan pengkatagorian di atas, maka dapat diketahui jumlah mahasiswa yang mempunyai kecerdasan interpersonal tinggi 8 orang dan kecerdasan interpersonal rendah 8 orang pada kelas kelompok komunikasi 1 sebagai kelas bedside teaching, mahasiswa yang mempunyai kecerdasan interpersonal tinggi 8 orang dan kecerdasan interpersonal rendah 8 orang pada kelas kelompok komunikasi 2 sebagai kelas coaching dan mahasiswa yang mempunyai kecerdasan interpersonal tinggi 8 orang dan kecerdasan interpersonal rendah 8 orang pada kelas kelompok komunikasi 3 sebagai kelas demonstrasi.

Hasil pengujian instrument kemampuan kognitif komunikasi terapeutik dari 70 butir soal yang telah di ujicoba terdapat 34 butir soal yang 
dinyatakan valid dengan nilai reabilitas sebesar 0,734. Hasil pengujian instrument kemampuan afektif komunikasi terapeutik dari 10 butir soal yang telah diujicoba terdapat 9 butir soal yang dinyatakan valid dengan reabilitas sebesar 0,941. Hasil pengujian instrument kemampuan psikomotor komunikasi terapeutik dari 17 butir soal yang diujicoba terdapat 14 butir soal yang dinyatakan valid dengan nilai reabilitas sebesar 0,981. Dan hasil pengujian instrument kecerdasan interpersonal dari 44 butir soal yang telah diujicoba terdapat 28 butir soal yang dinyatakan valid dengan reabilitas sebesar 0,971 . Teknik analisis data pada penelitian ini adalah (1) uji persyaratan analisis yaitu normalitas menggunakan uji Liliefors dan homogenitas menggunakan uji Bartlett, dan (2) Uji Hipotesis dengan menggunakan analisis varians (ANAVA) dan dilanjutkan dengan Uji Tukey.

\section{HASIL PENELITIAN DAN PEMBAHASAN}

Pengujian hipotesis dalam penelitian ini berkaitan dengan pengaruh utama (main effect) variabel bebas, yaitu metode bedside teaching, coaching dan demonstrasi. Rangkuman hasil penghitungan uji hipotesis adalah sebagai berikut:

Tabel 1 Rangkuman uji hipotesis dengan ANOVA

\begin{tabular}{|l|c|c|c|c|c|}
\hline $\begin{array}{c}\text { Sumber } \\
\text { Varians }\end{array}$ & JK & Db & RJK & $F_{0}$ & $\begin{array}{c}F_{\text {tab }} \\
\alpha=0,05\end{array}$ \\
\hline Antar A & 13,57 & 2 & 6,785 & 10,172 & 3,32 \\
\hline Antar B & 2,740 & 1 & 2,740 & 4,108 & 4,07 \\
\hline Interaksi AB & 38,263 & 2 & 19,131 & 28,682 & 3,32 \\
\hline Dalam & 28,34 & 42 & 0,667 & - & - \\
\hline Total & 82,913 & 47 & - & - & - \\
\hline
\end{tabular}

Hasil penghitungan analisis ANOVA pada sumber varians interaksi $\mathrm{AxB}$ secara signifikan terdapat interaksi antara metode pembelajaran dan kecerdasan interpersonal terhadap kompetensi komunikasi terapeutik yang dibuktikan dengan $\mathrm{F}_{0}$ $(\mathrm{A})=28,682>\mathrm{F}_{\mathrm{tab}}=3,32$, maka perlu dilakukan uji lanjut dengan uji Tuckey dan hasil penghitungan disajikan pada Tabel 2. Berdasarkan hasil uji analisis ANOVA dan uji Tukey di atas, dapat dijelaskan sebagai berikut:

Tabel 2. Rangkuman uji lanjut dengan uji Tukey

\begin{tabular}{|c|c|c|c|c|}
\hline Nilai Kontras & $(\mathrm{Se})$ & $\mathrm{t}_{0}$ & $\mathrm{t}_{\text {tabel }}$ & keputusan \\
\hline$\overline{\mathrm{Y}}_{11}-\overline{\mathrm{Y}}_{21}=1,50$ & 0,408 & 3,676 & 2,0181 & Signifikan \\
\hline$\overline{\mathrm{Y}}_{11}-\overline{\mathrm{Y}}_{31}=1,30$ & 0,408 & 3,186 & 2,0181 & Signifikan \\
\hline$\overline{\mathrm{Y}}_{21}-\overline{\mathrm{Y}}_{31}=0,82$ & 0,408 & 2,021 & 2,0181 & Signifikan \\
\hline$\overline{\mathrm{Y}}_{12}-\overline{\mathrm{Y}}_{22}=0,50$ & 0,408 & 1,22 & 2,0181 & Tidak Signifikan \\
\hline$\overline{\mathrm{Y}}_{12}-\overline{\mathrm{Y}}_{32}=1,50$ & 0,408 & 3,676 & 2,0181 & Signifikan \\
\hline$\overline{\mathrm{Y}}_{22}-\overline{\mathrm{Y}}_{32}=1,00$ & 0,408 & 2,450 & 2,0181 & Signifikan \\
\hline
\end{tabular}


Perbedaan kompetensi komunikasi terapeutik pada mahasiswa DIII Kebidanan STIKes Mitra RIA Husada yang diajarkan menggunakan metode bedside teaching dengan metode coaching

Berdasarkan perhitungan ANOVA seperti terlihat pada Tabel 5.3, pada sumber varians A menunjukkan bahwa nilai $\mathrm{F}_{0}=10,172>\mathrm{F}_{\mathrm{tab}}=$ 3,32 maka, Hipotesis $\mathrm{H}_{0}$ ditolak atau kompetensi komunikasi terapeutik pada mahasiswa DIII Kebidanan STIKes Mitra RIA Husada yang diajarkan menggunakan metode bedside teaching lebih tinggi dari yang diajarkan menggunakan metode coaching.

Pembuktian hipotesis berdasarkan kajian empiris yang dilakukan peneliti didukung oleh teori dan konsep yang dikemukakan oleh pakar seperti yang dikutip pada BAB II. Sesuai tujuan metode pembelajaran bedside teaching yaitu meliputi mengembangkan keterampilan interpersonal (developing interpersonal skills), mengembangkan interaksi pengajar, mahasiswa dan pasien, mengembangkan role-modeling. Didukung juga dengan pernyataan bahwa metode pembelajaran bedside teaching dapat meningkatkan pembelajaran aktif (active learning). Selain itu juga hasil penelitian ini didukung oleh Penelitian Piriyasupong (2009:14), meneliti pengaruh bedside teaching dalam pembelajaran evidence-based medicine pada mahasiswa kedokteran tahun kelima di Khon Khaen Hospital, Thailand. Diperoleh hasil penelitian bahwa metode bedside teaching efektif untuk pembelajaran evidence-based medicine.

Perbedaan kompetensi komunikasi terapeutik pada mahasiswa DIII Kebidanan STIKes Mitra RIA Husada yang diajarkan menggunakan metode bedside teaching dengan metode demonstrasi
Berdasarkan hasil perhitungan ANOVA (Tabel 5.3) pada sumber varians A menunjukkan bahwa nilai $\mathrm{F}_{0}=10,172>\mathrm{F}_{\mathrm{tab}}=3,32$ maka, Hipotesis $\mathrm{H}_{0}$ ditolak atau kompetensi komunikasi terapeutik pada mahasiswa DIII Kebidanan STIKes Mitra RIA Husada yang diajarkan menggunakan metode bedside teaching lebih tinggi dari yang diajarkan menggunakan metode demonstrasi.

Pembuktian hipotesis berdasarkan kajian empiris yang dilakukan peneliti didukung oleh teori dan konsep yang dikemukakan oleh pakar seperti yang dikutip pada BAB II. Penelitian Nair, Coughlan and Hensley (1997:10), meneliti pembelajaran keterampilan profesional pada mahasiswa kedokteran melalui metode bedside teaching. Diperoleh hasil penelitian bahwa bedside teaching sangat efektif untuk mengajarkan keterampilan profesional. Selain itu juga didukung oleh penelitian Solikhah dan Elsanti (2012:146) mengatakan terdapat perbedaan pengaruh metode bedside teaching terhadap penguasaan kasus mahasiswa praktek klinik keperawatan. Diperkuat lagi dengan penelitian Giyanto (2016:2), bahwa terdapat perbedaan pengaruh yang bermakna antara metode pembelajaran bedside teaching dengan metode pembelajaran demonstrasi terhadap kompetensi komunikasi terapeutik mahasiswa.

Perbedaan kompetensi komunikasi terapeutik antara mahasiswa DIII Kebidanan STIKes Mitra RIA Husada yang diajarkan menggunakan metode coaching dengan metode demonstrasi

Berdasarkan hasil perhitungan ANOVA (Tabel 5.3) pada sumber varians A menunjukkan bahwa $\mathrm{F}_{0}=10,172>\mathrm{F}_{\text {tab }}=3,32$ maka, Hipotesis 
$\mathrm{H}_{0}$ ditolak atau kompetensi komunikasi terapeutik pada mahasiswa DIII Kebidanan STIKes Mitra RIA Husada yang diajarkan menggunakan metode coaching lebih tinggi dari yang diajarkan menggunakan metode demonstrasi.

Pembuktian hipotesis berdasarkan kajian empiris yang dilakukan peneliti didukung oleh teori dan konsep yang dikemukakan oleh pakar seperti yang dikutip pada BAB II. Penelitian Arita Murwani (2010:29) melaporkan kesimpulan penelitianya bahwa ada interaksi antara metode coaching dan motivasi belajar terhadap kompetensi melakukan pemasangan pipa endotracheal tube pada mahasiswa keperawatan. Selain itu juga didukung oleh penelitian Turlina (2013:19) bahwa metode coaching mampu meningkatkan kompetensi mahasiswa dalam melakukan pemasangan Implan.

\section{Interaksi antara metode pembelajaran dan kecerdasan interpersonal terhadap kompetensi komunikasi terapeutik pada mahasiswa DIII Kebidanan STIKes Mitra RIA Husada}

Berdasarkan hasil perhitungan ANOVA (Tabel 5.3) pada sumber varians Interaksi A x B menunjukkan bahwa nilai $\mathrm{F}_{0}=28,682>\mathrm{F}_{\mathrm{tab}}=$ 3,32. maka $H_{0}$ ditolak. Hal ini berarti bahwa metode pembelajaran memiliki pengaruh terhadap hasil kompetensi komunikasi terapeutik. Demikian pula sebaliknya. Dengan demikian hipotesis penelitian yang menyatakan bahwa terdapat interaksi antara metode pembelajaran dan kecerdasan interpersonal terhadap kompetensi komunikasi terapeutik teruji kebenarannya.
Perbedaan kompetensi komunikasi terapeutik antara mahasiswa DIII Kebidanan STIKes Mitra RIA Husada yang diajarkan dengan metode bedside teaching dan memiliki kecerdasan interpersonal tinggi dengan mahasiswa yang diajarkan dengan metode coaching dan memiliki kecerdasan interpersonal tinggi

Hasil uji lanjut dengan uji Tukey pada Tabel 5.4 menunjukkan bahwa kompetensi komunikasi terapeutik antara mahasiswa DIII Kebidanan STIKes Mitra RIA Husada yang diajarkan dengan metode bedside teaching dengan mahasiswa yang diajarkan dengan metode coaching dan memiliki kecerdasan interpersonal tinggi diperoleh nilai $\mathrm{t}_{0}=3,676>\mathrm{t}_{\mathrm{tab}}=2,0181 \mathrm{H}_{\mathrm{o}}$ ditolak, dengan demikian dapat dikatakan bahwa kompetensi komunikasi terapeutik mahasiswa yang diajarkan dengan metode bedside teaching dan memiliki kecerdasan interpersonal tinggi lebih tinggi daripada mahasiswa yang diajarkan dengan metode coaching dan memiliki kecerdasan interpersonal tinggi.

Metode pembelajaran bedside teaching merupakan pengajaran atau pembelajaran aktif yang dilakukan menggunakan pasien langsung sebagai media pembelajaran. Dengan kata lain bahwa mahasiswa diarahkan untuk mengembangkan keterampilan kompetensi komunikasi terapeutik dan meningkatkan partisifasi aktif kepada pasien setiap melakukan asuhan kebidanan. Metode coaching merupakan memberdayakan peserta dan memfasilitasi pembelajaran diri, pertumbuhan, pribadi dan perbaikan kinerja dalam melaksanakan asuhan kebidanan. Dengan kata lain dapat meningkatkan kemampuan kemandirian belajar dari mahasiswa dan mengatasi permasalahan yang dihadapi. Tetapi disisi lain metode coaching dipengaruhi 
oleh keterampilan komunikasi yang tidak memadai.

Kecerdasan interpersonal merupakan kemampuan seseorang untuk peka terhadap orang lain, memahami dan berinteraksi dengan orang lain sehingga harapanya mudah bersosialisasi dengan lingkungan sekitarnya. Setiap individu memiliki kecerdasan interpersonal tinggi dan rendah. Pada penelitian ini metode bedside teaching lebih efektif diterapkan pada mahasiswa yang memiliki kecerdasan interpersonal tinggi dari pada mahasiswa yang memiliki kecerdasan interpersonal rendah karena mahasiswa yang memiliki kecerdasan tinggi memiliki tiga dimensi utama yaitu menurut Anderson yaitu: 1) social sensitivity: kemampuan untuk merasakan dan mengamati reaksi individu untuk bisa merasakan dan mengamati perubahan orang lain 2) social insight: kemampuan untuk memahami dan mencari pemecahan masalah yang efektif dalam suatu interaksi 3) social communication: kemampuan berkomunikasi baik verbal maupun non verbal (Siregar dan Nara, 2011:99).

Perbedaan kompetensi komunikasi terapeutik antara mahasiswa DIII Kebidanan STIKes Mitra RIA Husada yang diajarkan dengan metode bedside teaching dan memiliki kecerdasan interpersonal tinggi dengan mahasiswa yang diajarkan dengan metode demonstrasi dan memiliki kecerdasan interpersonal tinggi

Hasil uji lanjut dengan uji Tukey pada Tabel 5.4 menunjukkan bahwa kompetensi komunikasi terapeutik antara mahasiswa DIII Kebidanan STIKes Mitra RIA Husada yang diajarkan dengan metode bedside teaching dengan mahasiswa yang diajarkan dengan metode demonstrasi dan memiliki kecerdasan interpersonal tinggi, diperoleh nilai $\mathrm{t}_{0}=3,186>\mathrm{t}_{\mathrm{tab}}$ $=2,0181$ maka $\mathrm{H}_{\mathrm{o}}$ ditolak. Dengan demikian dapat dikatakan bahwa kompetensi komunikasi terapeutik antara mahasiswa DIII Kebidanan STIKes Mitra RIA Husada yang diajarkan dengan metode bedside teaching dan memiliki kecerdasan interpersonal tinggi dengan mahasiswa yang diajarkan dengan metode demonstrasi dan memiliki kecerdasan interpersonal tinggi.

Hasil ini sejalan dengan pendapat yang dikemukakan oleh Sanjaya dan Wina (2009:150151) yaitu metode demonstrasi memerlukan persiapan yang lebih matang, sebab tanpa persiapan yang memadai demonstrasi bisa gagal, sehingga dapat menyebabkan metode ini tidak efektif. Persiapan yang dimaksud dapat meliputi keterampilan pendidik dan kesiapan mahasiswa yaitu kecerdasan interpersonal dan motivasi mahasiswa dalam melakukan komunikasi terapeutik kepada pasien.

Metode pembelajaran bedside teaching yang diberikan pada kelompok mahasiswa yang memiliki kecerdasan interpersonal tinggi memberikan kesempatan kepada mahasiswa untuk belajar secara kognitif melalui analisa kasus, secara efektif melalui interaksi langsung mahasiswa dengan pasien, serta secara psikomotor melalui praktik langsung pada pasien. Sebaliknya, metode pembelajaran demonstrasi memberikan hasil yang lebih rendah karena mahasiswa hanya memperoleh kesempatan belajar secara kognitif melalui analisa kasus, secara efektif melalui interaksi mahasiswa tidak langsung pada pasien, serta secara psikomotor melalui observasi terhadap peragaan yang dilakukan oleh pembimbing klinik. 
Perbedaan kompetensi komunikasi terapeutik antara mahasiswa DIII Kebidanan STIKes Mitra RIA Husada yang diajarkan dengan metode coaching dan memilki kecerdasan interpersonal tinggi dengan mahasiswa yang diajarkan dengan metode demonstrasi dan memiliki kecerdasan interpersonal tinggi

Hasil uji lanjut dengan uji Tukey pada

Tabel 5.4 menunjukkan bahwa kompetensi komunikasi terapeutik antara mahasiswa DIII Kebidanan STIKes Mitra RIA Husada yang diajarkan dengan metode coaching dengan mahasiswa yang diajarkan dengan metode demonstrasi dan memiliki kecerdasan interpersonal tinggi, diperoleh nilai $\mathrm{t}_{0}=2,021>\mathrm{t}_{\mathrm{tab}}$ $=2,0181 \mathrm{H}_{0}$ ditolak. Dengan demikian bahwa kompetensi komunikasi terapeutik pada mahasiswa DIII Kebidanan STIKes Mitra RIA Husada yang diajarkan dengan metode coaching dan memilki kecerdasan interpersonal tinggi lebih tinggi daripada mahasiswa yang diajarkan dengan metode demonstrasi dan memiliki kecerdasan interpersonal tinggi.

Hasil ini sejalan dengan pendapat yang dikemukakan di Bab II, bahwa manfaat keuntungan dari metode coaching adalah peserta didik merasa lebih termotivasi dan bertanggung jawab untuk melakukan keterampilan yang baru dipelajari karena bimbingan berlangsung terus menerus dan personal. Sehingga mahasiswa dapat melakukan praktek dengan baik kepada pasien. Hal ini sejalan dengan penelitian Lestari dan Kartini, bahwa ada perbedaan yang signifikan pada pembelajaran dengan metode coaching dan demonstrasi terhadap kemampuan melakukan pemeriksaan leopold (Lestari dan Kartini, 2012:11). Berdasarkan hal ini dapat ditarik kesimpulan bahwa metode coaching lebih efektif digunakan dalam pembelajaran daripada metode demonstrasi.

Perbedaan kompetensi komunikasi terapeutik antara mahasiswa DIII Kebidanan STIKes Mitra RIA Husada yang diajarkan dengan metode bedside teaching dan memiliki kecerdasan interpersonal rendah dengan mahasiswa yang diajarkan dengan metode coaching dan memiliki kecerdasan interpersonal rendah

Hasil uji lanjut dengan uji Tukey pada Tabel 5.4 menunjukkan bahwa kompetensi komunikasi terapeutik antara mahasiswa DIII Kebidanan STIKes Mitra RIA Husada yang diajarkan dengan metode bedside teaching dengan mahasiswa yang diajarkan dengan metode coaching dan memiliki kecerdasan interpersonal rendah, diperoleh nilai $\mathrm{t}_{0}=1,22<\mathrm{t}_{\mathrm{tab}}=2,0181 \mathrm{H}_{0}$ ditolak. Dengan demikian bahwa, terdapat perbedaan kompetensi komunikasi terapeutik antara mahasiswa DIII Kebidanan STIKes Mitra RIA Husada yang diajarkan dengan metode bedside teaching dan memiliki kecerdasan interpersonal rendah dengan mahasiswa yang diajarkan dengan metode coaching dan memiliki kecerdasan interpersonal rendah.

Hasil ini sejalan dengan pendapat yang dikemukakan di BAB II bahwa metode bedside teaching merupakan pembelajaran aktif. Pembelajaran aktif merupakan pembelajaran yang memberikan kesempatan kepada mahasiswa untuk aktif membangun sendiri konsep dan makna melalui berbagai kegiatan. Pembelajaran aktif ini membutuhkan aktifitas berpikir tingkat tinggi. Menurut penelitian Suardana, Wiarta dan Sujana (2014) terdapat hubungan yang signifikansi secara bersama-sama antara interpersonal 
intelligence dan motivasi belajar dengan hasil belajar.

Perbedaan kompetensi komunikasi terapeutik antara mahasiswa DIII Kebidanan STIKes Mitra RIA Husada yang diajarkan dengan metode bedside teaching dan memiliki kecerdasan interpersonal rendah dengan mahasiswa yang diajarkan dengan metode demonstrasi dan memiliki kecerdasan interpersonal rendah

Hasil uji lanjut dengan uji Tukey pada Tabel 5.4 menunjukkan bahwa perbedaan kompetensi komunikasi terapeutik antara mahasiswa DIII Kebidanan STIKes Mitra RIA Husada yang diajarkan dengan metode bedside teaching dengan mahasiswa yang diajarkan dengan metode demonstrasi dan memiliki kecerdasan interpersonal rendah, diperoleh nilai $t_{0}$ $=3,676>\mathrm{t}_{\mathrm{tab}}=2,0181 \mathrm{H}_{0}$ diterima. Dengan demikian bahwa, tidak terdapat perbedaan kompetensi komunikasi terapeutik antara mahasiswa DIII Kebidanan STIKes Mitra RIA Husada yang diajarkan dengan metode bedside teaching dan memiliki kecerdasan interpersonal rendah dengan mahasiswa yang diajarkan dengan metode demonstrasi dan memiliki kecerdasan interpersonal rendah.

Hasil ini sejalan dengan pendapat yang dikemukakan di BAB II bahwa Bedside teaching adalah pembelajaran yang dilakukan langsung didepan pasien. Dengan bedside teaching mahasiswa dapat menerapkan ilmu pengetahuan, melaksanakan kemampuan komunikasi, keterampilan klinik dan profesionalisme, menemukan seni pengobatan, mempelajari bagaimana tingkah laku dan pendekatan dokter/bidan kepada pasien. Prinsip dasar dari bedside teaching adalah adanya kesiapan fisik maupun psikologis dari pembimbing klinik, peserta didik dan klien. Salah satu faktor psikologi adalah intelegensi yang merupakan di antara berbagai faktor yang dapat mempengaruhi bedside teaching, faktor intelegensi sangat besar pengaruhnya dalam proses dan kemajuan pembelajaran peserta didik. Apabila peserta didik memiliki intelegensi tinggi akan mudah untuk memperoleh hasil pembelajaran yang baik begitu juga sebaliknya jika peserta didik memiliki intelegensi rendah maka hasil pembelajaran kurang.

Metode Demonstrasi ialah metode mengajar dengan menggunakan peragaan untuk memperjelas suatu pengertian atau untuk memperlihatkan bagaimana berjalannya suatu proses pembentukan tertentu pada peserta didik (Kurniasih dan Berlin Sani, 2015:85). Dalam mengajar peserta didik lebih mudah diberikan pelajaran dengan cara menirukan seperti apa yang dilakukan pembimbingnya. Dalam hal ini, pembimbing mengajar melalui demonstrasi. Demonstrasi berarti menunjukkan, mengerjakan dan menjelaskan. Metode demonstrasi perlu dilakukan dalam rangka pengembangan motivasi peserta didik karena mengingat kecenderungan anak untuk mencontoh atau meniru orang lain sebagai salah satu naluri yang sangat kuat. Salah satu kekurangan metode demonstrasi adalah demonstrasi memerlukan kemampuan dan keterampilan tenaga pendidik yang lebih professional. Selain itu juga metode demonstrasi memerlukan kemauan dan motivasi yang baik untuk keberhasilan proses pembelajaran. Apabila hal tersebut tidak dimiliki mahasiswa susah menyerap proses pembelajaran dengan baik terutama pada mahasiswa yang memiliki 
kecerdasan interpersonal rendah. Karena dibutuhkan komunikasi dua arah antara pasien dan mahasiswa dalam melakukan pembelajaran praktek.

Berdasarkan pernyataan diatas kompetensi komunikasi terapeutik dapat ditingkatkan apabila mahasiswa memiliki kecerdasan interpersonal tinggi dengan metode pembelajaran yang tepat, sebaliknya apabila mahasiswa memiliki kecerdasan interpersonal rendah, maka kompetensi komunikasi terapeutik kurang apabila metode pembelajaran yang digunakan kurang tepat. Maka dapat disimpulkan bahwa, kompetensi komunikasi terapeutik antara mahasiswa yang diajarkan dengan metode bedside teaching dan memiliki kecerdasan interpersonal rendah lebih efektif daripada dengan mahasiswa yang diajarkan dengan metode demonstrasi dan memiliki kecerdasan interpersonal rendah.

Perbedaan kompetensi komunikasi terapeutik antara mahasiswa DIII Kebidanan STIKes Mitra RIA Husada yang diajarkan dengan metode coaching dan memiliki kecerdasan interpersonal rendah dengan mahasiswa yang diajarkan dengan metode demonstrasi dan memiliki kecerdasan interpersonal rendah

Hasil uji lanjut dengan uji Tukey pada Tabel 5.4 menunjukkan bahwa perbedaan kompetensi komunikasi terapeutik antara mahasiswa DIII Kebidanan STIKes Mitra RIA Husada yang diajarkan dengan metode coaching dengan mahasiswa yang diajarkan dengan metode demonstrasi dan memiliki kecerdasan interpersonal rendah, diperoleh nilai $t_{0}=2,450>$ $\mathrm{t}_{\mathrm{tab}}=2,0181 \mathrm{H}_{0}$ ditolak. Dengan demikian bahwa, ada perbedaan kompetensi komunikasi terapeutik antara mahasiswa DIII Kebidanan STIKes Mitra
RIA Husada yang diajarkan dengan metode coaching dan memiliki kecerdasan interpersonal rendah dengan mahasiswa yang diajarkan dengan metode demonstrasi dan memiliki kecerdasan interpersonal rendah.

Hasil ini sejalan dengan pendapat yang dikemukakan di BAB II bahwa faktor penghambat dalam menggunakan metode coaching adalah kepercayaaan peserta didik yang dipengaruhi fasilitator, kurangnya motivasi dari fasilitator dan keterampilan komunikasi mahasiswa yang tidak memadai. Faktor keterbatasan metode demonstrasi adalah apabila mahasiswa tidak aktif maka metode demonstrasi menjadi tidak efektif (Kurniasih dan Berlin Sani, 2015:86). Kecerdasan interpersonal berhubungan dengan kemampuan bekerja sama dan berkomunikasi baik verbal maupun non-verbal dengan orang lain. Rendahnya tingkat kecerdasan interpersonal mahasiswa ketika proses pembelajaran memicu mahasiswa malas bertanya, sehingga mahasiswa hanya menunggu yang diperintahkan pembimbing dan interaksi hanya berjalan satu arah.

Merujuk dari hal tersebut tugas utama seorang pembimbing hendaknya mampu merencanakan sebuah metode pembelajaran yang bervariasi agar dalam proses pembelajaran dapat tercapai hasil belajar yang optimal karena melalui metode pembelajaran yang bervariasi akan tercipta suasana yang interaktif antara mahasiswa dan pembimbing. Kecerdasan interpersonal juga memiliki peran penting bagi mahasiswa karena metode pembelajaran yang digunakan dengan didukung kecerdasan interpersonal tersebut dapat mempengaruhi proses pembelajaran mahasiswa 
sehingga hasil belajar akan tercapai sesuai dengan harapan.

\section{KESIMPULAN}

Berdasarkan hasil penelitian, analisis data dan pembahasan dapat disimpulkan bahwa;

Pertama; kompetensi komunikasi terapeutik mahasiswa DIII Kebidanan STIKes Mitra RIA Husada yang diajarkan dengan metode bedside teaching tinggi lebih tinggi dari pada kompetensi terapeutik mahasiswa yang diajarkan dengan metode coaching dan metode demonstrasi

Kedua; kompetensi komunikasi terapeutik mahasiswa yang belajar dengan metode pembelajaran coaching lebih tinggi daripada kompetensi terapeutik mahasiswa yang belajar dengan metode demostrasi.

Ketiga; terdapat interaksi antara metode pembelajaran dan kecerdasan interpersonal terhadap kompetensi komunikasi terapeutik.

Keempat; hasil belajar mahasiswa yang memiliki kecerdasan interpersonal tinggi dan menggunakan metode bedside teaching lebih tinggi dibandingkan kelompok mahasiswa yang menggunakan metode coaching dan demonstrasi. Oleh sebab itu untuk mahasiswa dengan kecerdasan interpersonal tinggi lebih relevan menggunakan metode bedside teaching.

Kelima; hasil belajar mahasiswa yang memiliki kecerdasan interpersonal rendah lebih tinggi menggunakan metode coaching bila dibandingkan dengan mahasiswa yang menggunakan metode demonstrasi. Dengan demikian untuk mahasiswa yang memiliki kecerdasan interpersonal rendah, lebih relevan jika menggunakan metode coaching dari pada metode demonstrasi.

\section{DAFTAR PUSTAKA}

Albright, Zappe, dan Winston. 2011. Data Analysis, Optimization, and Simulation Modeling.Cengage Learning: Canada.

Daryanto. 2008. Administrasi Pendidikan. Rineka Cipta: Jakarta.

Deborah Gill. 2003. Teaching and Learning 'At the Bedside' Academic Centre for Medical Education: London

Donald Ary, Lucy Cheser Jacobs dan Chris Sorenson. 2010. Introduction to research in education. Cengage Learning: Canada.

Giyanto. 2010. Pengaruh metode pembelajaran dan motivasi belajar terhadap kompetensi komunikasi terapeutik mahasiswa program profesi Ners. (Pascasarjana Surakarta). $\quad$ http://eprints.uns.ac.id (diakses 13 Mei 2016).

Hamzah. 2014. Variabel penelitian dalam Pendidikan dan pembelajaran. Ina Publikatama: Jakarta.

Herve Abdi, Betty Edelman, Dominique Valentindan W. Jay Dowling. 2009. Experimental Design and Analysis for Psychology Oxford University Press: New York

Jack R. Fraenkel, Norman E. Wallen dan Helen H. Hyun. 2012. How to Design and Evaluate Research in Education McGraw-Hill: New York.

Kurniasih, Imas dan Berlin Sani. 2015. Ragam Pengembangan Model Pembelajaran Kata Pena: Yogyakarta.

Lestari, Dwi dan Farida Kartini. 2016. Perbedaan Pembelajaran Metode Coaching dan Demonstrasi terhadap Kompetensi 
Melakukan Pemeriksaan Leopold pada Mahasiswa Semester II STIKes Yogyakarta. http://opac.unisayogya.ac.id (diakses 13 Mei 2016).

L. R. Gay, Geoffrey E. Mills dan Peter Airasian. 2009. Educational Research: Competencies for Analysis and Applications. Pearson : Columbia.

Meredith D. Gall, Joyce P. Gall dan Walter R. Borg. 2007. Educational Research: An Introduction. Pearson: Columbia.

Murwarni, Arita. 2010. Pengaruh Metode Bimbingan Coaching dan Motivasi terhadap Kompetensi Pemasangan Endotrakeal Tube pada Mahasiswa STIKes Surya Global Yogyakarta. (Pascasarjana Surakarta) https://digilib.uns.ac.id. (diakses 13 Mei 2016).

Nair B, Coughlan J, Hensley M. 1997. "Student and Patient Perspectives on Bedside Teaching," Medical Education, Vol. 31, Blackwell Science Ltd.

Piriyasupong T. 2008. "Integrating Evidence Based Medicine In Bedside Teaching: A Pilot Study" dalam South East Asian Journal of Medical Education, Volume 2, No. 1. http://www.medicaleducation.com (diakses: 3 Januari 2009).

Sanjaya dan Wina. 2009. Strategi Pembelajaran berorientasi Standar Proses Pendidikan. Kencana: Jakarta.
Siahaan, Sofyan dan Madjid. 2004. Bidang Menyongsong Masa Depan. IBI: Jakarta.

Siregar dan Nara. 2011. Teori Belajar dan Pembelajaran Ghalia Indonesia: Bogor.

Solikhah dan Elsanti. 2012. "Pengaruh bedside teaching model terhadap penguasaan kasus dan kemampuan keterampilan mahasiswa praktik klinik keperawatan" (Purwokerto: Jurnal Keperawatan Soedirman. Vol. 7).

Suardana, Wiarta dan Sujana. 2014. Hubungan antara Interpersonal Intelligence dan Motivasi Belajar dengan Hasil Belajar IPS Siswa Kelas V SDN Gugus Letkol I Gusti Ngura Rai Denpasar. Vol 2 (1). Jurnal Mimbar PGSD: Denpasar.

Titik Puji Lestari, Susilaningsih dan Sri rahayu. 2009. "Efektifitas metode pembelajaran bedside teaching terhadap kemampuan psikomotor mahasiswa Kebidanan Bakti Husada," Jurnal Kesehatan, Vol. 7 (2). Poltekkes Depkes: Malang.

Theresa L. White dan Donald H. McBurney. 2013. Research Methods. Cengage Learning : Canada.

Turlina, Lilin. 2013. "Pengaruh Metode Bimbingan dan Motivasi Belajar terhadap Kompetensi Mahasiswa tentang Pemasangan Implan di STIKes Muhammadyah Lamongan". Jurnal Kesehatan, Vol. 02. STIKes Muhammadyah: Lamongan. 